\title{
Clover root weevil (Sitona lepidus) in New Zealand: the story so far
}

\author{
J.P.J. EERENS, S. HARDWICK, P.J. GERARD and B.E. WILLOUGHBY \\ AgResearch, Ruakura Research Centre, PB 3123, Hamilton \\ han.eerens@agresearch.co.nz
}

\begin{abstract}
The rapid spread of clover root weevil (Sitona lepidus) (CRW) since its introduction in the early 1990s, threatens the competitive advantage of New Zealand's pastoral industry. When CRW was discovered, it had already spread too far for containment. The insect's distribution currently covers the North Island and there is no reason to prevent its spread ultimately throughout NZ. With no competing species, CRW is more damaging in NZ than in its native Europe. Clover root weevil affects white clover nitrogen $(\mathrm{N})$ fixation while simultaneously reducing the clover content of pastures thereby lowering total forage quality. Legume germplasm was screened for resistance/tolerance and while no resistance was discovered, vigorous growing white clover plants showed tolerance to CRW and gains from selection for tolerance were achieved. Eliminating remnant clover before pasture renovation or growing a crop between grass stages reduces the resident CRW population and improves clover re-establishment. How ever, CRW can reinvade and potentially return to its original density. Two candidate biological control agents are being pursued for release later in 2005. Clover root weevil's impact on pastoral farming varies, partially due to environmental variation, which dictates clover growth and CRW development.
\end{abstract}

Keywords: clover root weevil, cultivar selection, life cycle analysis, pasture management, Sitona lepidus

\section{Introduction}

Geographical isolation has shielded NZ from many pests and diseases and the country's extensive biosecurity control systems aims to keep unwanted organisms out. However, rising levels of international trade and traffic (Gadgil et al. 2000) carry an inherent risk of unwanted organisms entering NZ. Some pests do escape initial detection and become established (Goldson et al. 2002). A new species entering the country often does so free of diseases and predators. Consequently it goes through an explosive population increase causing severe damage before settling down at a level at which population size and food supply are in balance (Goldson et al. 2002).

Clover root weevil (Sitona lepidus) (CRW) probably entered NZ in the early 1990s but went undetected until 1996 (Barrett et al. 1996), by which time it had spread over 200000 ha and containment was impossible. On arrival, it found an environment free of diseases and predators, rich in its preferred food source, white clover (Trifolium repens) all supportive of rapid population growth. The initial population explosion caused near complete white clover elimination on many farms. Without the clover to support the next generation, weevil numbers plummeted and the smaller residual population allowed partial clover recovery (boom and bust cycles), fluctuating around an equilibrium of typically 200-300 $\mathrm{CRW} / \mathrm{m}^{2}$ with a mean pasture clover content of $10 \%$ in the Waikato. This pattern is repeated in every newly invaded region, resulting in permanently lowered clover content in pastures compared to pre-CRW levels. The loss of clover reduces the level of $\mathrm{N}$ fixation, along with a loss of forage quality. For pastoral farmers this has major consequences especially where reliance on clover-fixed $\mathrm{N}$ is high. Ultima tely, production is lower and costs are higher, as the loss of $\mathrm{N}$ fixation will be compensated by increasing mineral fertiliser $\mathrm{N}$ applications.

An extensive research effort was initia ted after CRW had been confirmed in NZ, and a picture of the pest potential of CRW is de veloping. Published papers relating to pest impact and management are reviewed here along with some additional, as yet unpublished, research data.

\section{Spread}

Initially CRW was found in two se parate areas (Bay of Plenty and Auckland), but these merged and expansion continued throughout the North Island (Fig. 1). In Europe, CRW has a wide climatic range from the Mediterranean to Finland, suggesting that all of NZ will ultimately be CRW infested. Currently there is no evidence that CRW has reached the South Island. However detection of adult CRW presence depends on a large number of notched clover leaves, the result of a relatively high CRW population. Since detection of small larval populations requires a major sampling effort, it is therefore likely that a population will be well established by the time it is detected.

\section{Life cycle and pest impact}

Once CRW has established, temperature and rainfall determine pest impact levels from year-to-year. Developmental studies indicate three generations/yr for Northland, two generations for most of the North Island and Nelson/Marlborough with a single generation expected in cooler southern regions (Gerard et al. 
Figure 1 Spread of CRW over the North Island from 1996 to mid-2005.

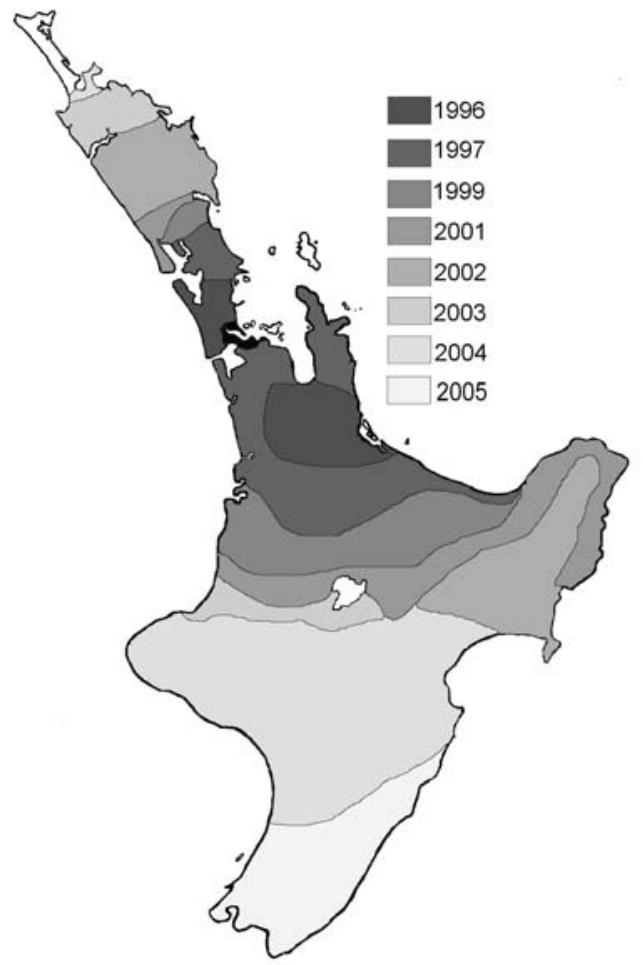

1999). In the Waikato, CRW population size is determined by early summer rainfall. In dry years, the summer populations are small because few eggs are laid and egg and larval survival is low (Gerard et al. 1999). Adult CRW are generally either i) predominantly reproductive and flightless or ii) have flight muscles for dispersal and are non-reproductive. For example, in cool, moist conditions, around $90 \%$ of CRW females are reproductive and only $4 \%$ have flight muscles, while in hot, dry conditions, these numbers are 32 and $35 \%$ respectively (Gerard \& Amold 2002).

Clover root weevil females lay their eggs above ground and hatched larvae quickly burrow to seek out active nodules on clover roots (Hackell \& Gerard 2004). As larvae mature, they feed on progressively larger roots and final instars attack nodal roots and stolons (Gerard et al.2004). This damage impairs all aspects of root function, increasing sensitivity to stresses such as competition, drought and pasture mismanagement. The larvae pupate in the soil and the main periods of adult emergence are in late-spring and autumn. The adults can live many months and feed on clover foliage, with a marked preference for newly established seedlings (Hardwick \& Harens 2000). This compromises seedling establishment from the seedbank or during renovation.
Larval numbers in the soil are determined by environmental conditions (Eerens \& Hardwick 2003) and clover nodule availability and accessibility. In a favoura ble year over $10000 \mathrm{CRW}$ eggs $/ \mathrm{m}^{2} \mathrm{can}$ be laid although more typically it is $2500-3500 / \mathrm{m}^{2}$ (Gerard unpublished data). Larval survival is directly related to the number of nodules available/larva (Gerard 2001). During peak oviposition periods in early summer and autumn, competition for available clover nodules will both limit CRW larval establishment and have major consequences for white clover's $\mathrm{N}$ fixation ability (Gerard 2001).

\section{Economic impact of CRW}

A small plot trial has shown that even when clover is not stressed, modest larval densities of 300-350 larvae $/ \mathrm{m}^{2}$ in second year pasture reduced clover dry matter (DM) production in the 6-month period from September to February by $34 \%$ (Gerard unpublished data). While $\mathrm{CRW}$ has a big impact on $\mathrm{N}$ fixation, animal production suffers from reduced forage quality. An accurate assessment of these impacts is difficult as it varies depending on environmental conditions. Clover's contribution to total DM production is cyclic in nature, making it impossible to accurately allocate damage to CRW presence. If CRW reduced the white clover contribution (forage and $\mathrm{N}$ fixation) nationwide by $10 \%$, annual damage would amount to $\$ 300$ million based on its current valuation of $\$ 3$ billion (Caradus et al. 1996).

\section{Clover root weevil tolerant species}

Several legume field evaluation trials have been conducted (Eerens et al. 2001a; Watson et al. 2002; Crush et al. 2004) but no evidence of resistance to CRW has been found in white clover. Lines with strong agronomic performance were least affected by CRW (Eerens et al. 2001a), especially nematode tolerant lines. Clover root weevil adults showed a high feeding preference for white clover and caucasian clover (Trifolium ambiguum), followed by red clover ( $T$. pratense). Minimal feeding damage was observed on lotus species (Lotus corniculatus, L. pedunculatus) and lucerne (Medicago sativa). The initial evaluation was based on leaf damage but later evaluations also assessed soil fauna around the roots (Crush et al. 2004). Despite greater CRW susceptibility, the a gronomic performance of white clover was still far superior to that of the other species (Eerens et al. 2001a). Care et al. (2000) found that long fine rooted clover genotypes, with greater initial root mass, tended to have a higher proportion of effective root left after a CRW attack. With two root primordia formed at every node in white clover (Thomas 1987), this suggests that cultivars with a 
Table 1 Effect of pre-sowing treatment on the number of clover seedlings and early DM production $(\mathrm{kg} / \mathrm{ha})$.

\begin{tabular}{lccc}
\hline & Clover & \multicolumn{2}{c}{ Clover DM production (\% of total DM) } \\
& seedlings $/ \mathrm{m}^{2}$ & Spring 2004 & Summer 2004/05 \\
\hline Brassica & 62 & $660(10.5)$ & $480(30.4)$ \\
Maize & 44 & $430(8.6)$ & $430(29.2)$ \\
Grass & 25 & NA & $180(8.5)$ \\
\hline
\end{tabular}

residues minimises UV and heat damage to stolons (Watson et al. 1996). With the loss of nodules and reduced $\mathrm{N}$ fixation inputs, frequent applications of small amounts of $\mathrm{N}$ immediately after grazing will be needed to assist in maintaining production levels. greater nodal density would have increased tolerance to CRW. Such a positive correlation between stolon length/plant and number of nodes would allow a plant to quickly grow beyond its original size, the basis on which plant vigour and superior agronomic performance is determined.

\section{Pasture management}

Pasture management practices in NZ have become increasingly unfavourable for clover as $\mathrm{N}$ application rates increased, more vigorous ryegrass cultivars are used and spring and summer grazing patterns changed from clover to grass management. Clover levels were already declining and CRW is an additional stress factor. By relieving some of the stress factors, e.g. irrigation in summer dry areas, clover productivity can improve even under high CRW densities (Eerens \& Hardwick 2003).

Clover root weevil cannot survive in the soil in the absence of clover (Bell et al. 2004). When renovating pastures, breaking the grass-to-grass cycle by incorporating a crop, reduces/eliminates CRW, which benefits clover establishment (Table 1). For example, more seedlings were counted 55 days after autumn sowing and the clover proportion was higher when pastures were sown following either a brassica or maize crop compared to sowing grass-to-grass. This results in a clear benefit to clover establishment even though the pests will gradually re-invade over time.

In areas where Argentine stem weevil (Listronotus bonariensis) population densities are high, sowing ryegrass with an endophyte (Neotyphodium lolii) content of around $70 \%$ assists white clover proliferation in the first year (Eerens et al. 2001b). Sowing ryegrass seed with an endophyte content in excess of $90 \%$ will result in a dense highly competitive sward suppressing white clover. The gradual removal of ryegrass tillers at a time when temperatures are at an optimum for white clover growth allows clover to occupy the gaps in the sward. These measures all aim to achieve a strong clover population consisting of healthy vigorous growing plants, more tolerant of CRW.

Once CRW has re-infested a paddock, pasture management needs to promote white clover without reducing total productivity. Frequent spring grazing minimises grass competition, while higher summer

\section{Biological control options}

Two potential biological control options are currently being investigated. A search of Europe identified Microctonus aethiopoides as a potential parasitoid candida te (Goldson et al. 2004a). A Moroccan strain of this species was successfully introduced into NZ in the 1980 s to control $S$. discoideus (lucerne weevil) but has proved ineffective against CRW. The Moroccan strain and the newly discovered European strain can potentially mate, raising questions about the progeny's ability to effectively control either or both target species. However the discovery in Ireland of a parthenogenetic (uniparental sexual reproduction) M. aethiopoides strain, effective against $\mathrm{CRW}$, makes this hybridisation issue irrelevant, especially if the parthenogenesis is robust (Goldson et al. 2004b).

A few CRW adults both in NZ and Europe were found to be infected with the fungus Beauveria bassiana, with the European strain being more virulent (Glare et al. 2004). Glasshouse experiments have indicated this control option has potential and is now being field tested.

\section{Conclusion}

Clover root weevil has the potential to become a nationwide pest reducing the productivity of white clover-based pastures, increasing production costs and negatively impacting on the environment. The economic impact will vary regionally, depending on the damage CRW causes to clover densities and $\mathrm{N}$ fixation. With no CRW resistance available, farmers will have to implement more clover-friendly pasture management practices and select CRW-tolerant clover strains. Biological control options may become available later in 2005, but need time before impacting on CRW population densities. Even when fully established, the best that can be hoped for is a reduction in the CRW population rather than complete elimination as pest and bio-control agents go through boom and bust cycles and variable levels of CRW damage to clover are likely to be present at all times.

\section{REFERENCES}

Barratt, B.I.P.; Barker, G.M.; Addison, P.J. 1996. Sitona lepidus Gyllenhal (Coleoptera: Curculionidae), a potential clover pest new to New Zealand. New 
Zealand Entomologist 19: 23-30.

Bell, N.L.; Addison, P.J.; Kettlewell, F.J.; Eden, T.M. 2004. The effect of autumn plant host removal on abundance of the clover root weevil (Sitona lepidus) and white clover seedling establishment. Proceedings of the Australasian Conference on Grassland Invertebrate Ecology 8: 172-176.

Caradus, J.R.; Woodfield, D.R.; Stewart, A.V. 1996. Overview and vision for white clover. White clover: New Zealand's Competitive Edg e. Agronomy Society of New Zealand Special Publication 11/Grassland Research and Practice Series 6: 1-6.

Care, D.A.; Crush, J.R.; Hardwick, S.; Nichols, S.N.; Ouyang, L. 2000. Interaction between clover root weevil and clover root type. New Zealand Plant Protection 53:420-424.

Crush, J.R.; Cooper, B.M.; Woodfield, D.R.; Eerens, J.P.J.; Gerard, P.J.; Watson, R.N.; Davis, L.T. 2004. Selection of pasture legumes for tolerance of clover root weevil. Proceedings of the Australasian Conference on Grassland Invertebrate Ecology 8: 58-64.

Eerens, J.P.J.; Cooper, B.M.; Willoughby, B.E.; Woodfield, D.R. 2001a. Searching for clover root weevil (Sitona lepidus) resistance/tolerance - A progress report. Proceedings of the New Zealand Grassland Association 63: 177-181.

Eerens, J.P.J.; Crush, J.R.; Woodward, S.L.; Macdonald, K.A.; Carter, W.A. 2001b. Milksolids production from different combinations of perennial ryegrass and white clover: I. Trial design and pasture performance. Proceedings of the New Zealand Grassland Association 63: 91-96.

Eerens, J.P.J.; Hardwick, S. 2003. Factors affecting clover root weevil (Sitona lepidus) numbers and clover production. New Zealand Journal of Agricultural Research 46: 305-310.

Gadgil, P.D.; Bulman, L.S.; Crabtree, R.; Watson, R.N.; O'Neil, J.C.; Glassey, K.L. 2000. Significance to New Zealand forestry of contaminants on the external surfaces of shipping containers. New Zealand Joumal of Forestry 30: 341-358.

Gerard, P.J. 2001. Dependence of Sitona lepidus (Coleoptera: Curculionidae) larvae on abundance of white clover Rhizobium nodules. Bulletin of Entomological Research 91: 149-152.

Gerard, P.J.; Amold, E.D. 2002. Influence of climate regime on clover root weevil adult survival and physiology. New Zealand Plant Protection 55: 241245.

Gerard, P.J.; Addison, P.J.; Hardwick, S.; Willoughby,
B.E. 1999. Establishment of the invader: Insights into life history and biology of Sitona lepidus in the Waika to region of New Zealand. Proceedings of the Australasian Conference on Grassland Invertebrate Ecology 7: 43-51.

Gerard, P.J.; Hackell, D.L.; Willoughby, B.E. 2004. Insights into clover root weevil larval feeding. Proceedings of the Australasian Conference on Grassland Invertebrate Ecology 8: 49-57.

Glare, T.R.; Willoughby, B.E.; Nelson, T.L.; Wilson, D.J.; Eden, T.M. 2004. Towards a fungal biopesticide for clover root weevil. Proceedings of the Australasian Conference on Grassland Invertebrate Ecology 8: 112- 117.

Goldson, S.L.; Barlow N.D.; Gerard, P.J.; Jackson, T.A.; Phillips, C.B.; Watson, R.N.; Rahman, A. 2002. Biosecurity for New Zealand's forage production systems. Proceedings of the New Zealand Grassland Association 64: 135-138.

Goldson, S.L.; McNeill, M.R.; Gerard, P.J.; Proffitt, J.R.; Phillips, C.B.; Cane, R.P.; Murray, P.J. 2004a. British-based search for natural enemies of the clover root weevil, Sitona lepidus in Europe. New Zealand Journal of Zoology 31: 233-240.

Goldson, S.L.; McNeill, M.R.; Proffitt, J.R.; Gerard, P.J.; Phillips, C.B. 2004b. The quest for biological control of the clover root weevil and the importance of ecotypes. Proceedings of the Australasian Conference on Grassland Invertebrate Ecology 8: 107-111.

Hackell, D.L.; Gerard, P.J. 2004: Nodule preference by first instar clover root weevil. New Zealand Plant Protection 57: 319-322.

Hardwick, S.; Harens, B. The behaviour of adult Sitona lepidus Gyllenhal (Coleoptera: Curculionidae) in response to white clover. New Zealand Plant Protection 53: 415-419.

Thomas, R.G. 1987. Vegetative growth and development. pp. 31-62. In: White clover. Eds. Baker, M.J.; Williams, W.M. CAB International, Wallingford, UK.

Watson, R.N.; Eerens, J.P.J.; Davis, L.T. 2002. Clover root weevil feeding and larval numbers on white and red clover seedlines. New Zealand Plant Protection 55: 252-257.

Watson, R.N.; Harris, S.L.; Bell, N.L.; Neville, F.J. 1996. Deferred grazing to enhance white clover content in pastures. White clover: New Zealand's Competitive Edge. Agronomy Society of New Zealand Special Publication 11/Grassland Research and Practice Series 6: 154. 